
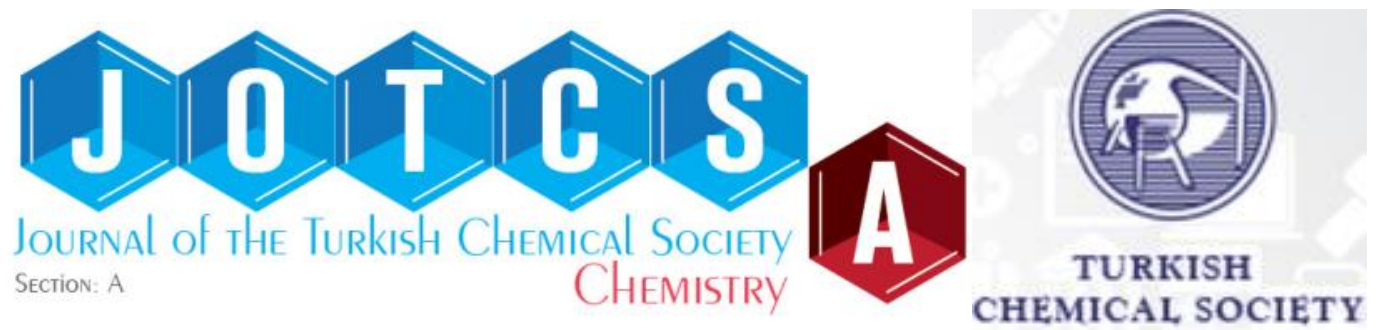

\title{
Synthesis of Dihydrobenzofuranone Derivatives with Biotechnological Methods
}

\author{
Zerrin ZERENLER ÇALIŞKAN* \\ ${ }^{1}$ Yildiz Technical University, Faculty of Science and Arts, Department of Molecular Biology and Genetics, \\ Davutpasa Campus, Davutpasa St. No: 127, Esenler 34210, Istanbul-TURKEY
}

Abstract: Benzofuranone derivatives have important skeletons which are widely present in various biologically active molecules, thus, synthesis of optically pure compounds presents great interest for medicinal chemistry. In our study, the enantioselective synthesis of 4-oxo-6-phenyl-4,5,6,7tetrahydrobenzofuran-5-yl acetate (3) and 4-oxo-6-phenyl-4,5,6,7-tetrahydrobenzofuran-5-ol derivative (4) was achieved for the first time. Several lipases were used for the kinetic resolution of different $\mathrm{pH}$ values and different solvent systems of racemic 4-oxo-6-phenyl-4,5,6,7-tetrahydrobenzofuran-5-yl acetate (rac-3) in which the lipases from HPL, PPL, RNL and PCL displayed high enantioselectivity towards 4-oxo6-phenyl-4,5,6,7-tetrahydrobenzofuran-5-ol derivative (4) at $\mathrm{pH}=7$.

Keywords: benzofuranone; enzyme-mediated hydrolysis; kinetic resolution

Submitted: July 27, 2018. Accepted: October 22, 2018.

Cite this: Zerenler Çalışkan Z, Ay E. Synthesis of Dihydrobenzofuranone Derivatives with Biotechnological Methods. JOTCSA. 2018;5(3):1221-32.

DOI: http://dx.doi.org/10.18596/jotcsa.448551.

*Corresponding author. E-mail: zcalis@yildiz.edu.tr.

\section{INTRODUCTION}

The compounds bearing a benzofuranone skeleton are found to have potential for large scale implementation as pharmacological agents because of their biological activity (1).

The benzofuranone derivatives with important biological activity are present in a large range of natural products and also therapeutic substances. Therefore, benzofuranone derivatives are encouraged in the design and synthesis of thousands of benzofuranone-containing pharmaceuticals (2). Some benzofuranonecontaining drugs are capable lead compounds that could possibly be useful as potent anti-tumor agents against several human cancer cell lines (310).

It is known that benzofuranones are significant intermediates used in the synthesis of natural products. For example, the use of benzofuranone is reported as a most important intermediate for the main and total synthesis of taxol (7).

There is demand for the development of synthetic methodologies leading to the structure of chiral benzofuranone-type compounds, considering the attractive pharmaceutical effects and different biological properties of the afore-mentioned 
natural products, drugs and other related products.

The synthesis of drugs discovered through efficient stereoselective synthetic methods is one of the most current industrial research subjects. There are significant variations in the pharmacological activities of the enantiomers. There are chiral receptor domains in the human body, which interact only with drug molecules with an acceptable absolute configuration. For this reason, the relationship between molecular chirality and pharmacological activity is very important in pharmacology (11).

Nowadays, with the discovery of modern medicines, the prominence of enzymatic kinetic solution reactions has emerged $(12,13)$. From the broad range of enzymatic classes, lipases have improved and have attracted attention owing to their stereoselective-wide substrate, ease of use, non-requirement of added cofactors and low cost $(14,15)$. These kinds of enzymes are also used in the enantioselective hydrolysis of acetoxy enones which are widely used in enantioselective esterification reactions of optically active alcohols, carboxylic acids and esters in organic solvents (16).

In the literature, there are not many examples of enzymatic resolution of 4-oxo-tetrahydro benzofuranone derivatives which have multifunctional structural benefits. For this reason, it is important to develop new methods for preparing benzofuranone derivatives, which are significant compounds in pharmacy in enantiomerically pure form. In the synthetic procedure, new benzofuranone derivatives with optically pure form were obtained under the guidance of our previous work $(17,18)$. As a part of our ongoing research, we examined the reaction of compound 2 via $\mathrm{Mn}(\mathrm{OAc})_{3}$ and 4-oxo6-phenyl-4,5,6,7-tetrahydrobenzofuran-5-yl acetate (rac-3) was obtained. Afterwards, these compounds can be used as important intermediates in medicinal chemistry. Kinetic resolution was performed in the presence of various lipase enzymes of different $\mathrm{pH}$ values and different solvent systems. Therefore, optically active a-hydroxy derivative was achieved as a high enantiomerically pure compound.

\section{EXPERIMENTAL}

\section{Materials and methods}

NMR spectra were obtained on a Bruker Avance III spectrometer at $500 \mathrm{MHz}$. Chemical shifts $\delta$ are reported in ppm relative to $\mathrm{CDCl}_{3}\left({ }^{1} \mathrm{H}\right.$ : $\delta=7.27), \mathrm{CDCl}_{3}\left({ }^{13} \mathrm{C}: \delta=77.0\right)$ and $\mathrm{CCl}_{4}\left({ }^{13} \mathrm{C}\right.$ : $\delta=96.4$ ) as internal standards. Column chromatography was performed on silica gel 60 (40-63 $\mu \mathrm{m})$. TLC was implemented on silica gel $60 \mathrm{~F}_{254}$ (Merck), and the spots were observed with UV light $(\lambda=254 \mathrm{~nm})$. IR spectra were recorded on a Perkin Elmer Spectrum 100 FT-IR Spectrometer. Enantiomeric excesses were defined by HPLC analyses using an Agilent 1100 Series supplied with a suitable chiral phase column. Lipases WGL (Wheat Germ Lipase) BioChemika (62306), CAL B (Candida Antarctica Lipase B) BioChemika (62288), CCL (Candida Cyclindracea Lipase) BioChemika (62316), HPL (Hog Pancreas Lipase) BioChemika (62300), MJL (Mucor Javanicus Lipase) BioChemika (62304), PLL (Pseudomonas Lipoprotein Lipase) BioChemika (62335), PCL (Penicillum Camemberti Lipase) BioChemika (96888), PRL (Penicillum Roqueforti Lipase) BioChemika (62323), and CRL (Candida Rugosa Lipase) BioChemika (74793) were taken from a Fluka lipase basic kit (62327). Only Amano Lipase PS from Burkholderia Cepacia (Pseudomonas Cepacia) was obtained from Aldrich (534641). Optical rotations were determined with Bellingham Stanley ADP-410 electronicautomation Sucromat digital automatic saccharimeter. Mass spectra were measured with 
an Agilent G6530B instrument quadrupole time of flight LC/MS instrument.

\section{General Procedure for the synthesis of 4-} oxo-4,5,6,7-tetrahydrobenzofuran (19)

Chloroacetaldehyde $\left(\mathrm{C}_{2} \mathrm{H}_{3} \mathrm{ClO}, 40 \%\right.$ solution, 20 $\mathrm{mL}$ ) and $\mathrm{NaHCO}_{3}(10 \mathrm{~g})$ were added into water $(80 \mathrm{~mL})$ at $0-5{ }^{\circ} \mathrm{C}$. To this mixture, an aqueous solution of 5-phenyl-1,3-cyclohexanedione (1) (1880 $\mathrm{mg} / 9 \mathrm{~mL}$ ) was added drop wise (0.4 $\mathrm{mL} / \mathrm{min}$ ) with stirring. After the addition, the reaction mixture was further stirred overnight at room temperature. Throughout the reaction, the acidity of the solution was within $\mathrm{pH}=6-9$. To the mixture, ethyl acetate (ca. $100 \mathrm{~mL}$ ) was added, and the resulting solution was acidified $(\mathrm{pH}=1)$ and stirred for 1 hour. The organic layer was separated, washed with aqueous $\mathrm{K}_{2} \mathrm{CO}_{3}$ solution, dried over $\mathrm{MgSO}_{4}$, and concentrated. The crude product was purified by column chromatography (1:1:6 EtOAc: n-hexane: $\mathrm{CHCl}_{3}$ ) to yield $6,7-$ dihydro-6-phenylbenzofuran-4 (5H) -one (2).

\section{General procedure for $\mathrm{Mn}(\mathrm{OAc})_{3}$ oxidation}

$7.5 \mathrm{mmol} \mathrm{Mn}(\mathrm{OAc})_{3}$ in $100 \mathrm{~mL}$ benzene-acetic acid (10:1) was refluxed. To this solution, 1.8 $\mathrm{mmol}$ of benzofuranone was added and reflux was continued for $42 \mathrm{~h}$. After all the starting material was consumed, the reaction mixture was extracted with diethyl ether and the organic layer was washed with brine. The resulting organic phase was dried over $\mathrm{MgSO}_{4}$ and concentrated under vacuum. The crude product was purified by column chromatography (1.5:10:0.5 EtOAc: $n$ hexane: $\mathrm{CHCl}_{3}$ ) to yield acetoxy-benzofuranone.

\section{General procedure for the lipase-catalyzed} kinetic resolution

Lipase (200-300 mg) was dissolved in phosphate buffer $(\mathrm{pH} 7,300 \mu \mathrm{L})$ and added to a solution of the pure substrate $(0.5 \mathrm{mmol})$ in the solvent $(3$ $\mathrm{mL}$ ) and the reaction mixture was left to shake at $37{ }^{\circ} \mathrm{C}$. Conversion was monitored by TLC and HPLC up to $50 \%$. Then, the filtrate was extracted with chloroform, dried over $\mathrm{MgSO}_{4}$, concentrated and purified by column chromatography (1:7:1 EtOAc: Hexane: $\mathrm{CHCl}_{3}$ ).

\section{6,7-Dihydro-6-phenylbenzofuran-4 (5H)- one (2)}

Yield: $127.2 \mathrm{mg}, 60 \%$. IR $\left(\mathrm{CHCl}_{3}\right) \vee=1673.14$ $\mathrm{cm}^{-1} .{ }^{1} \mathrm{H}$ NMR (500 MHz, $\left.\mathrm{CDCl}_{3}\right) \delta(\mathrm{ppm}): 2.79$ $(\mathrm{m}, 2 \mathrm{H}), 3.14(\mathrm{~m}, 2 \mathrm{H}), 3.57(\mathrm{~m}, 1 \mathrm{H}), 6.74(\mathrm{~d}, \mathrm{~J}$ $=1.6 \mathrm{~Hz}, 1 \mathrm{H}), 7.31(\mathrm{~m}, 5 \mathrm{H}) .{ }^{13} \mathrm{C} \mathrm{NMR}(500 \mathrm{MHz}$, $\left.\mathrm{CDCl}_{3}\right) \delta(\mathrm{ppm}): 31.20,41.37,45.02,106.54$, $121.04,126.75,127.29,128.92,142.46,143.46$, $166.34,193.07$.

\section{4,5,6,7-tetrahydro-6-phenyl-4-oxo- benzofuran-5-yl acetate (3)}

Yield: 865 mg, 60\%, white crystals, (mp: 115,3 $\left.{ }^{\circ} \mathrm{C}\right)$. IR $\left(\mathrm{CHCl}_{3}\right) \vee=1679.25,1219.38 \mathrm{~cm}^{-1} .{ }^{1} \mathrm{H}-$ NMR (500 MHz, $\left.\mathrm{CDCl}_{3}\right) \delta(\mathrm{ppm}): 1.98$ (s, 3H), $3.27(\mathrm{~m}, 2 \mathrm{H}), 3.29(\mathrm{~d}, 1 \mathrm{H}), 3.73(\mathrm{~m}, \mathrm{H}), 5.84(\mathrm{~d}$, $\mathrm{J}=12.5 \mathrm{~Hz}, 1 \mathrm{H}), 6.74(\mathrm{~d}, \mathrm{~J}=2.0 \mathrm{~Hz}, 1 \mathrm{H}), 7.35$ $(\mathrm{m}, 5 \mathrm{H}) .{ }^{13} \mathrm{C}-\mathrm{NMR}\left(500 \mathrm{MHz}, \mathrm{CDCl}_{3}\right) \delta$ (ppm): 20.44, 31.40, 46.56, 76.70, 107.01, 120.17, $127.46,127.74,128.86,139.08,144.01,164.42$, 170.15, 187.32. LCMS (ES-QTOF) m/z: Anal. Calcd for $\mathrm{C}_{16} \mathrm{H}_{14} \mathrm{O}_{4}$ 270,08921; Found: 271,0946 $[\mathrm{M}+\mathrm{H}]^{+}$.

\section{(+)-4,5,6,7-tetrahydro-6-phenyl-4-oxo-}

benzofuran-5-yl acetate $(+)-3$

Yield: $20.20 \mathrm{mg}, 15 \%$. [a]D $\mathrm{D}^{20}$ : $-0,03$ (c 0.01, $\left.\mathrm{CHCl}_{3}\right)$; HPLC: Chiralcell OD-H column, UV detection at $254 \mathrm{~nm}$, eluent: $n$-hexane/2propanol $=9: 1$, flow $1.0 \mathrm{~mL} \min ^{-1} 20{ }^{\circ} \mathrm{C}$, retention time: $14.5 \mathrm{~min}$.

\section{(+)-4,5,6,7-tetrahydro-6-phenyl-4-oxo-}

\section{benzofuran-5-ol (+)-4}

Yield: $53.50 \mathrm{mg}, 47 \%$. (mp: $\left.105,5^{\circ} \mathrm{C}\right)$. IR $\left(\mathrm{CHCl}_{3}\right)$ $v=3462.36 \mathrm{~cm}^{-1}, 2922.17 \mathrm{~cm}^{-1} .{ }^{1} \mathrm{H}-\mathrm{NMR}(500$ $\left.\mathrm{MHz} \mathrm{CDCl}_{3}\right): \delta(\mathrm{ppm})=3.15(\mathrm{~m}, 2 \mathrm{H}), 3.35(\mathrm{~m}$, $1 \mathrm{H}), 3.73(\mathrm{~s}, 1 \mathrm{H}), 4.51(\mathrm{~d}, \mathrm{~J}=11.9 \mathrm{~Hz}, 1 \mathrm{H}), 6.68$ $(\mathrm{d}, \mathrm{J}=2.0 \mathrm{~Hz}, 1 \mathrm{H}), 7.3(\mathrm{~m}, 5 \mathrm{H}) .{ }^{13} \mathrm{C}-\mathrm{NMR}(500$ $\left.\mathrm{MHz}, \mathrm{CDCl}_{3}\right): \delta(\mathrm{ppm})=31.44,49.44,76.64$, 
$106.80,118.74,127.67,128.96,140.09,144.13$, 166.34, 193.86. LCMS (ES-QTOF) m/z: Anal. Calcd for $\mathrm{C}_{14} \mathrm{H}_{12} \mathrm{O}_{3} 228,07864$; Found: 229,0845 $[\mathrm{M}+\mathrm{H}]^{+}$.

[a]D $D^{20}=+18.18\left(\mathrm{c} 0.01, \mathrm{CHCl}_{3}\right)$; HPLC: Chiralcell OD-H column, UV detection at $254 \mathrm{~nm}$, eluent: $n$ hexane/2-propanol $=9: 1$, flow $1.0 \mathrm{~mL} \mathrm{~min}^{-1} 20$ ${ }^{\circ} \mathrm{C}$, retention time: $24 \mathrm{~min}$.

\section{RESULTS AND DISCUSSIONS}

The use of enzyme-mediated processes for enantioselective transformations is of great interest for a large range of enzymatic species, such as lipases which have gained much interest in recent years because of their easy handling, low expense, and broad substrate region. It is known that in the enantioselective reactions of the hydrolysis of esters and acylation of alcohols, lipase-type enzymes are generally used. In this work, chiral hydroxy benzofuranone derivatives with high potential for biological activity were synthesized. Enzymatic biotransformation of the synthesized chiral hydroxybenzofuranone compounds was performed to determine the enantiomeric excess (e.e.) values.<smiles>CC(C)C1CC(=O)CC(c2ccccc2)C1</smiles>

(1)
(2)<smiles>CC(=O)OC1C(=O)c2ccoc2CC1c1ccccc1</smiles>

(rac-3)<smiles>O=C1c2ccoc2CC(c2ccccc2)[C@H]1O</smiles>

(4)<smiles>CC(=O)OC1C(=O)c2ccoc2CC1c1ccccc1</smiles>

(3)

Scheme 1. (a) Chloroacetaldehyde $\left(\mathrm{C}_{2} \mathrm{H}_{3} \mathrm{ClO}\right)$, (b) $\mathrm{Mn}(\mathrm{OAc})_{3}$, benzene/AcOH, reflux; (c) enzyme; solvent, $\mathrm{pH}=7,35^{\circ} \mathrm{C}$.

Initially, the synthesis of 6,7-dihydro-6phenylbenzofuran-4(5H)-one (2) was performed from commercially available 5-phenyl-1,3cyclohexadione (1) using the method of Matsumoto and Watanabe (19) even though an alternative reaction of 1,3-cycloadditions to olefins was available $(20,21)$. Nevertheless, in our study the Matsumoto and Watanabe method was used for obtaining the compound (2) due to its general ease of reaction condition, one-step reaction and the convenient commercial availability of the starting materials. Then, selective oxidations of 6,7-dehydro-6phenylbenzofuran-4(5H)-one (2) were performed in the presence of manganese(III) acetate. As is known, many scientists have published different studies with $\mathrm{Mn}$ (III) acetate, which is known as a regioselective acetylation reagent (22). Therefore, (rac-3) compound was to be synthesized by the reaction of (2) and 
Mn(III) acetate as the oxidizing agent in benzene as the solvent, in the light of these publications $(23,24)$. Then the enzyme-mediated hydrolysis reaction of a-acetoxyenone was performed to ensure production of compound (3) and compound (4) with high enantiomeric excess and great yields (Scheme 1 ).

To obtain the ideal conditions for the enzymatic hydrolysis of rac-3, we applied analytical screening. To do that, the reactions were made in analytical scale. The lipases were used for enantioselective hydrolysis of a-acetoxy enones. Because of the low solubility of the substrate in aqueous medium, a few milliliters of organic solvent was also necessary. DMSO, toluene or THF was used for this purpose. About $0.5 \mathrm{mmol}$ of acetoxy enone was dissolved in a minimum amount of organic solvent. All reactions were carried out in phosphate buffer $(\mathrm{pH}=7$ or $\mathrm{pH}=6$ or $\mathrm{pH}=8$ ) at room temperature. For $0.5 \mathrm{mmol}$ of acetoxy enone, 300- $\mu \mathrm{L}$ phosphate buffer was added. Subsequently, the enzyme was added to the mixture and the mixture was stirred at $37 \mathrm{C}$. The reaction was observed by TLC. At the point where approximately $50 \%$ conversion was observed, chloroform was added to terminate the reaction.

In our ongoing work, we have previously provided information related to biocatalyst-mediated reactions $(17,18,25)$. Here, we performed enzymatic hydrolysis of rac-3 by using a variety of lipase enzymes which were used for analytical screening (Table 1 ).

Twelve different enzymes were used to find the enzyme that gave the best results: WGL (Wheat Germ Lipase), Amano Lipase, CAL B (Candida Antarctica Lipase B), CCL (Candida Cyclindracea Lipase), MJL (Mucor Javanicus Lipase), HPL (Hog Pancreas Lipase), PCL (Penicillum Camemberti Lipase), PLL (Pseudomonas Lipoprotein Lipase), PRL (Penicillum Roqueforti Lipase), RAL (Rhizopus
Arrhizus Lipase), RNL (Rhizopus Niveus Lipase), and CRL (Candida Rugosa Lipase) were realized, as summarized in Table 1 . In the kinetic resolution step, three different organic solvents (DMSO, Toluene, and THF) were tested. They were also tested in phosphate buffer at $\mathrm{pH}=6$, $\mathrm{pH}=7$, and $\mathrm{pH}=8$ for the enzymatic hydrolysis step in DMSO. HPLC with chiral cell OD-H column was used to determine the enantiomeric excess of acetate and alcohol.

To specify the conversion, the reaction was monitored with TLC and HPLC as references by using a chiral column using rac-3 (synthesized from rac-3 with $\mathrm{K}_{2} \mathrm{CO}_{3} / \mathrm{MeOH}$ ). The reaction was followed at regular intervals by TLC and terminated when $50 \%$ conversion was reached. The pure product was obtained after flash column chromatography.

Because of the worldwide use of lipases, there is a need to understand the mechanisms of lipasecatalyzed reactions in organic solvents. Since most lipases easily become denatured in organic solvents and therefore lose their catalytic activities, it becomes important to find lipases that are stable in non-aqueous systems. Lipases act in organic solvents and are connected with their capacity in both synthetic and hydrolytic reactions.

It has also been found that the various lipases behave differently in different organic solvents with different reaction systems. However, so far, none of them has enabled validation of any serious predictive analysis about catalysis in organic solvents (26). In this study, the effect of solvents was investigated and it was observed that esterification in hydrophobic solvents such as toluene and DMSO generally provided relatively high enantiomeric excess for alcohol (+)-(4). However, the hydrophilic solvents such as THF gave low yields, and very low enantiomeric excess values (Table 1 ). 
All results are summarized in Table 1 . The best results for the hydroxy enones with PPL for the high enantioselectivity $81 \%$ ee, $24 \%$ conversion and $E$ value: 11 were obtained for the reaction at $\mathrm{pH}=7$ in DMSO (entry 19). According to the preparative scale, the PPL (Pseudomonas Lipoprotein Lipase) enzyme was used for the synthesis of (+)-4 (Table 1 , entry 19), which gives the best result with the highest enantiomeric excesses ( $81 \%$ ee, $47 \%$ yield) in the presence of DMSO.

Changing the enzyme as well as the solvent affected the enantioselectivity of the reaction. As the results show, $81 \%$ enantiomeric excess was found in HPL (in toluene) (entry 14), PPL (in toluene) (entry 20) and $80 \%$ RNL (in DMSO) (entry 31) for the hydroxy benzofuranone (+)-4. As shown in Table 1, the lipase Amano achieved $32 \%$ enantiomeric excess in toluene (entry 5 ), PPL with $25 \%$ enantiomeric excess in DMSO (entry 19), and PPL with $21 \%$ enantiomeric excess in toluene (entry 20), (-)-3 showing reverse selectivity.

In this study, the acetoxy enantiomer was not resolved in the high enantiomeric excess. The probable cause for this may be the presence of large groups such as the acetate groups in addition to the phenyl group on the ring.

In this paper, we examined the effects of $\mathrm{pH}$ as well as the solvent effect. Optimal $\mathrm{pH}$ determined the most effective enzyme activity point. Pepsin enzyme is very effective at $\mathrm{pH}$ 1.5-1.6 and urease enzyme shows maximum activity at $\mathrm{pH} 7$, which is a good example of the fact that enzymes can usually function in a narrow $\mathrm{pH}$ range (27). The structure and ionization state of the enzymes and reactants may be changed by monitoring the reaction of the $\mathrm{pH}$. Additionally, most of the enzymes possibly lose their influence either at higher or lower $\mathrm{pH}$ values. In order to find good ee values, the solvent and $\mathrm{pH}$ values were changed while keeping the enzyme the same. For an increase of enantiomeric excess value, DMSO with three different $\mathrm{pH}$ values was also tested.

The best results were in the MJL catalyzed resolution: at $\mathrm{pH}=6$, the determined ee values are $83 \%$ (entry 16 ), at $\mathrm{pH}=8$ the determined ee values are $59 \%$ (entry 18), in PPL catalyzed resolution at $\mathrm{pH}=7$ the determined ee values are $81 \%$ (entry 20) and at $\mathrm{pH}=6$ the determined ee values are $59 \%$ (entry 19 ), as can be seen in Table 2 for compound $(+) \mathbf{4}$.

Moreover, some enzyme and solvent combinations and phosphate buffer increased the $E$ value of the reaction (PPL with $81 \%$ ee and $E$ value: 11; (entry 20 in Table 1) for DMSO at $\mathrm{pH}=7$, PPL with $81 \%$ ee and $\mathrm{E}$ value: 10 ; (entry 20 in Table 1) for toluene at $\mathrm{pH}=7, \mathrm{PCL}$ with $79 \%$ ee and $\mathrm{E}$ value: 10; (entry 22 in Table 1) for DMSO at $\mathrm{pH}=7$ as indicated in (-)-(4). Additionally, high conversion values were achieved. The efficient conversion of the esterification in the RAL catalyzed solution was $61 \%$ with DMSO at $\mathrm{pH}=7$ which showed $23 \%$ ee for (-)-(4-oxo-6-phenyl-4,5,6,7tetrahydrobenzofuran-5-yl acetate) selectivity and $15 \%$ (+)-(4-oxo-6-phenyl4,5,6,7-tetrahydrobenzofuran-5-ol) selectivity (Table 1 , entry 28 ). 
Table 1. Enzymatic hydrolysis of (rac-3).

\begin{tabular}{|c|c|c|c|c|c|c|c|}
\hline Entry & Enzyme & Solvent & Time(d) & $\begin{array}{ll}\text { Alcohol } & \\
\text { ee }^{a}(\%) & \text { Yield } \\
\end{array}$ & $\begin{array}{l}\text { Acetate } \\
\text { ee }^{a}(\%)\end{array}$ & $\begin{array}{l}\text { Conversion } \\
\mathrm{C}(\%)\end{array}$ & $E^{c}$ \\
\hline 1 & \multirow{3}{*}{ WGL } & DMSO & 7 & 23 & 6 & 21 & 2 \\
\hline 2 & & Toluene & 4 & 45 & 9 & 19 & 2 \\
\hline 3 & & THF & $>26$ & - & 1 & - & - \\
\hline 4 & \multirow{3}{*}{ Amano Lipase } & DMSO & $>26$ & - & 16 & - & - \\
\hline 5 & & Toluene & 8 & - & $32 *$ & - & - \\
\hline 6 & & THF & $>26$ & - & 3 & - & - \\
\hline 7 & \multirow{3}{*}{ CAL B } & DMSO & $>26$ & - & 16 & - & - \\
\hline 8 & & Toluene & $>26$ & - & 2 & - & - \\
\hline 9 & & THF & $>26$ & - & 0.3 & - & - \\
\hline 10 & \multirow[b]{3}{*}{ CCL } & DMSO & $>26$ & 8 & 0.1 & 1 & 1 \\
\hline 11 & & Toluene & $>26$ & 9 & 2 & 20 & 1 \\
\hline 12 & & THF & $>26$ & 13 & 0.3 & 2 & 1 \\
\hline 13 & \multirow{3}{*}{ HPL } & DMSO & $>26$ & 9 & 1 & 10 & 1 \\
\hline 14 & & Toluene & $>26$ & 81 & 5 & 6 & 9 \\
\hline 15 & & THF & $>26$ & - & 0.07 & - & - \\
\hline 16 & \multirow{3}{*}{ MJL } & DMSO & $>26$ & - & 7 & - & - \\
\hline 17 & & Toluene & $>26$ & - & 2 & - & - \\
\hline 18 & & THF & $>26$ & 50 & 4 & 7 & 3 \\
\hline 19 & \multirow{3}{*}{ PLL } & DMSO & $>36$ & 81 yield: 47 & $25^{*}$ & 24 & 11 \\
\hline 20 & & Toluene & $>36$ & 81 & $21^{*}$ & 21 & 10 \\
\hline 21 & & THF & $>36$ & 66 & 1 & 2 & 3 \\
\hline 22 & \multirow{3}{*}{ PCL } & DMSO & $>36$ & 79 & 9 & 10 & 10 \\
\hline 23 & & Toluene & $>36$ & 47 & 4 & 8 & 3 \\
\hline 24 & & THF & $>36$ & - & 1 & - & - \\
\hline 25 & \multirow{3}{*}{ PRL } & DMSO & $>36$ & 38 & 7 & 16 & 2 \\
\hline 26 & & Toluene & $>36$ & 77 & 4 & 5 & 8 \\
\hline 27 & & THF & $>36$ & - & 0.5 & - & - \\
\hline 28 & \multirow{3}{*}{ RAL } & DMSO & $>36$ & 15 & $23 *$ & 61 & 2 \\
\hline 29 & & Toluene & $>36$ & - & 7 & - & - \\
\hline 30 & & THF & $>36$ & - & 0.5 & - & - \\
\hline 31 & \multirow{3}{*}{ RNL } & DMSO & $>36$ & 80 & 5 & 6 & 1 \\
\hline 32 & & Toluene & $>36$ & 1 & 10 & 91 & 1 \\
\hline 33 & & THF & $>36$ & 38 & 4 & 10 & 2 \\
\hline 34 & \multirow{3}{*}{ CRL } & DMSO & $>36$ & 2 & 3 & 60 & 1 \\
\hline 35 & & Toluene & $>36$ & 8 & 0.2 & 2 & 1 \\
\hline 36 & & THF & $>36$ & - & 0.5 & - & - \\
\hline
\end{tabular}

aDetermined Chiralcell OD-H column, eluent: $\mathrm{n}$-hexane/2 propanol $=9: 1$, flow $1.0 \mathrm{~mL} \mathrm{~min}-120{ }^{\circ} \mathrm{C}, \mathrm{UV}$ detection at $254 \mathrm{~nm},{ }^{b}$ Yield value was obtained using flash column chromatography.

'See Ref. (28). 
Table 2. Enzymatic hydrolysis of (rac-3) with different lipase enzymes at pH 6, pH 7, pH 8 and DMSO medium.

\begin{tabular}{|c|c|c|c|c|c|c|c|}
\hline Entry & Enzyme & Solvent & Time (d) & Alcohol & Acetate & Conversion & $\mathbf{E}^{\mathrm{c}}$ \\
\hline & & & & $e^{a}(\%)\left(y^{a}{ }^{2} d^{b}\right)$ & (\%) & & \\
\hline 1 & \multirow{3}{*}{ WG } & $\mathrm{pH} 6$ & 7 & 22 & 8 & 27 & 2 \\
\hline 2 & & $\mathrm{pH} 7$ & 7 & 23 & 6 & 21 & 2 \\
\hline 3 & & $\mathrm{pH} 8$ & 7 & 10 & 7 & 41 & 1 \\
\hline 4 & \multirow{3}{*}{ Amano Lipase } & $\mathrm{pH} 6$ & $>26$ & 13 & 3 & 19 & 1 \\
\hline 5 & & $\mathrm{pH} 7$ & $>26$ & - & 16 & - & - \\
\hline 6 & & $\mathrm{pH} 8$ & $>26$ & - & $20^{*}$ & - & - \\
\hline 7 & \multirow{3}{*}{ CAL B } & $\mathrm{pH} 6$ & $>26$ & 5 & 3 & 38 & 1 \\
\hline 8 & & $\mathrm{pH} 7$ & $>26$ & $\overline{-}$ & 16 & - & - \\
\hline 9 & & $\mathrm{pH} 8$ & $>26$ & 7 & 3 & 30 & 1 \\
\hline 10 & \multirow{3}{*}{ CCL } & $\mathrm{pH} 6$ & $>26$ & 6 & 1 & 14 & 1 \\
\hline 11 & & $\mathrm{pH} 7$ & $>26$ & 8 & 0.1 & 1 & 1 \\
\hline 12 & & $\mathrm{pH} 8$ & $>26$ & 7 & 0.3 & 4 & 1 \\
\hline 13 & \multirow{3}{*}{ HPL } & $\mathrm{pH} 6$ & $>26$ & - & 0.6 & - & - \\
\hline 14 & & $\mathrm{pH} 7$ & $>26$ & 9 & 1 & 10 & 1 \\
\hline 15 & & $\mathrm{pH} 8$ & $>26$ & 2 & 0.3 & 13 & 1 \\
\hline 16 & \multirow{3}{*}{ MJL } & $\mathrm{pH} 6$ & $>26$ & 83 & 5 & 6 & 1 \\
\hline 17 & & $\mathrm{pH} 7$ & $>26$ & - & 7 & - & 5 \\
\hline 18 & & $\mathrm{pH} 8$ & $>26$ & 59 & 5 & 8 & 4 \\
\hline 19 & \multirow{3}{*}{ PLL } & $\mathrm{pH} 6$ & $>36$ & 59 & $14 *$ & 19 & 5 \\
\hline 20 & & $\mathrm{pH} 7$ & $>36$ & $81(47)$ & $25^{*}$ & 24 & 11 \\
\hline 21 & & $\mathrm{pH} 8$ & $>36$ & 24 & 5 & 17 & 2 \\
\hline
\end{tabular}

a Determined with Chiralcell OD-H column, eluent: $\mathrm{n}$-hexane/2 propanol = 9:1, flow $1.0 \mathrm{~mL} \mathrm{~min}^{-1} 20{ }^{\circ} \mathrm{C}$, UV detection at $254 \mathrm{~nm},{ }^{b}$ Yield value was obtained using flash column chromatography.

'See Ref. (28).

Evaluations of different $\mathrm{pH}$ values of the acetoxy enantiomer (+/-)-3, which were not completely successful in producing enantiomeric excesses of esterification reactions, are summarized in Table 2. The lipases, Amano with $20 \%$ enantiomeric excess at $\mathrm{pH}=8$ (entry 6), $\mathrm{PPL}$ with $25 \%$ enantiomeric excess at $\mathrm{pH}=7$ (entry 20), and PPL with $14 \%$ enantiomeric excess at $\mathrm{pH}=6$ (entry $19)$, show reverse selectivity and (-)-3 is found.

In our previous study, we observed that the enzymatic kinetic resolution reactions gave related alcohol and acetate product in high yields with more than $99 \%$ enantiomeric excess. However, in this study we got a maximum value of $88 \%$ enantiomeric excess from esterification reactions. This clearly demonstrates that the identity of the phenyl group in the benzofuranone structure is very important and it may reduce the kinetic resolution process as seen from the enantiomeric excess values of the steric mass of the group. In our studies, we will continue to increase the enantiomeric excess and use different types of lipase enzymes as well as various microorganisms, and all cell systems will 
be used with different solvents at different $\mathrm{pH}$ values.

In this paper, the enantioselective syntheses of (3) and (4) were undertaken by using hydrolysis reactions in the presence of a lipase enzyme with moderately high enantiomeric excess for the first time in the literature.

As seen in Scheme 1, easy and efficient methods of benzofuranone formation (19) have been used for the synthesis of 6,7-dehydro-6phenylbenzofuran-4(5H)-one (2) with a good yield $(60 \%)$. It is known that $\mathrm{Mn}(\mathrm{OAc})_{3}$ which is used as an oxidizing agent, is important to functionalize the a- positions of the enones with high regioselectivity. For this reason, we used an effective oxidation procedure with 6,7-dihydro-6phenylbenzofuran-4 (5H)-one (2) and $\mathrm{Mn}(\mathrm{OAc})_{3}$. Thus, the desired product a-acetoxy-4-oxotetrahydrobenzofuranone (rac-3) derivative was successfully achieved.

It has been seen that enzyme-mediated hydrolysis of acetoxy enone (rac-3) gave only a single enantiomer of $(+)-(4)$ when using three different phosphate buffers and various enzyme and solvent combinations. However, the acetoxy enantiomer is not resolved with good enantiomeric excess. The (+)-3 and (-)-3 enantiomers are shown in Table 1 and Table 2.

\section{CONCLUSION}

Enzymatic biotransformation can be utilized as a tool for the drug industry. Herein, we focused on the chemoenzymatic synthesis of optically active benzofuranone derivatives which are very important in medicinal chemistry.

We anticipate that this work will provide a new viewpoint to chemists and will increase the interest in biocatalysts and active substance synthesis. In the present work, enantioselective synthesis of (3) and (4), which is a significant objective in pharmacology, through enzymatic kinetic resolution, was performed for the first time. Enzyme-catalyzed enantioselective hydrolysis of $(\mathbf{( - )}-\mathbf{3})$ was achieved with a $32 \%$ enantiomeric excess. The lipase-catalyzed esterification reactions of $(\mathbf{( + )}-\mathbf{4})$ had high enantiomeric excesses of $83 \%$. This method is an effective way for studies of the synthesis of compound (3) and compound (4) which could be used to develop optically pure drugs which are important for human health.

Such important research as this plays a significant role in simplifying the synthesis of desired products and relevant analogues for medicinal chemistry evaluation. This type of study lends itself to the improvement of new therapeutic agents.

\section{REFERENCES}

1. Keay BA, Hopkins JM, Dibble PW. Furans and their benzo derivatives: Applications. Comprehensive Heterocyclic Chemistry III. 2008:571-623.

2. Mishra RC. Second Generation Benzofuranone Ring Substituted Noscapine Analogs: Synthesis and Biological Evaluation. Biochemical Pharmacology. 2011; 82:110-21.

3. Tan YX, Wang HQ, Chen RY. Anti-inflammatory and cytotoxic 2-arylbenzofurans from Morus wittiorum. Fitoterapia. 2012; 83:750-3.

4. Tan YX, Yang $Y$, Zhang $T$, Chen RY, Yu DQ. Bioactive 2-arylbenzofuran derivatives from Morus wittiorum. Fitoterapia. 2010; 81:742-6.

5. Kim YJ, Sohn MJ, Kim WG. Chalcomoracin and moracin C, new inhibitors of Staphylococcus aureus enoyl-acyl carrier protein reductase from Morus alba. Biol Pharm Bull. 2012; 35: 791-5. 
6. Romagnoli R, Baraldi PG, Sarkar T, et al. Synthesis and biological evaluation of 2-aroyl-4phenyl-5-hydroxybenzofurans as a new class of antitubulin agents. Med Chem. 2008; 4:558-64.

7. Flynn BL, Gill GS, Grobelny DW, et al. Discovery of 7-hydroxy-6-methoxy-2-methyl-3(3,4,5-trimethoxybenzoyl)benzofuran (BNC105), a tubulin polymerization inhibitor with potent antiproliferative and tumor vascular disrupting properties. J Med Chem. 2011; 54:6014-27.

8. Shi W, Lowary TL. Structure-activity relationships in glycosylated 2-phenyl-indoles, 2phenyl-benzo $[b]$ thiophenes and 2phenylbenzo[b]furans as DNA binding and potential antitumor agents. Bioorg. Med. Chem. $2011 ; 19: 1779-89$.

9. Kossakowski J, Ostrowska K, Hejchman E, Wolska I. Synthesis and structural characterization of derivatives of 2- and 3benzo[b]furan carboxylic acids with potential cytotoxic activity. II Farmaco. 2005; 60:519-27.

10. George JH, Baldwin JE, Adlington RM. Enantiospecific, biosynthetically inspired formal total synthesis of $(+)$-liphagal. Org Lett. 2010; 12:2394-7.

11. Caner H, Groner E, Levy L, Agranat I. Trends in the development of chiral drugs. Drug Discovery Today. 2004; 9(3):105-10.

12. Carey JS, Laffan D, Thomson C, Williams MT. Analysis of the reactions used for the preparation of drug candidate molecules. Org. Biomol. Chem. 2006; 4:2337-47.

13. Gotor V, Alfonso I, García-Urdiales E. Asymmetric Organic Synthesis with Enzymes. Weinheim, Germany: Wiley-VCH; 2008.
14. Patel RN. Synthesis of chiral pharmaceutical intermediates by biocatalysis. Coord. Chem. Rev. 2008; 252:659-701.

15. Hudlicky $T$, Reed JW. Applications of biotransformations and biocatalysis to complexity generation in organic synthesis. Chem. Soc. Rev. 2009; 38(11):3117-32.

16. Schnell B, Faber K, Kroutil W. Enzymatic Racemisation and its Application to Synthetic Biotransformations. Adv. Synth. Catal. 2003; 345: 653-66.

17. Demir AS, Caliskan Z, Sahin E. Enantioselective synthesis of 4,5,6,7-tetrahydro4-oxo-benzofuran-5-yl acetate and 1-benzyl4,5,6,7-tetrahydro-4-oxo-1(H)-indol-5-yl acetate using chemoenzymatic methods. Journal of Molecular Catalysis B: Enzymatic. 2007; 44:8792.

18. Caliskan ZZ, Ersez MS. Stereoselective synthesis of optically active1-benzyl-4,5,6,7tetrahydro-6,6-dimethyl-4-oxo-1H-indol-7ylacetate and 1-benzyl-6,7-dihydro-7-hydroxy6,6-dimethyl-1H-indol-4(5H)-onethrough lipasecatalyzed esterification and transesterificationprocesses. J. Mol. Catal. B: Enzym. 2015; 111:64-70.

19. Matsumoto $M$, Watanabe N. A facile synthesis of 4-oxo-4,5,6,7-tetrahydroindoles. Heterocycles. $1984 ; 22: 2313-6$.

20. Xia L, Lee $Y R$, Kim SH, Lyoo WS. AgBF4 /[Bmim]BF4-catalyzed [3+2] cycloaddition of cyclic diazodicarbonyl compounds. Efficient synthesis of 2,3-dihydrofurans and conversion to 3-acylfurans. Bulletin of the Korean Chemical Society. $2011 ; 32(5)$ : 1554-8.

21. Mueller P, Allenbach YF, Bernardinelli G. On the Enantioselectivity of Transition Metal- 
Catalyzed 1,3-Cycloadditions of 2Diazocyclohexane-1,3-diones. Helvetica Chimica Acta. 2003; 86(9): 3164-78.

22.(a) Heiba EI, Dessau RM, Koehl WJJr. Oxidation by metal salts. IV. A new method for the preparation of $\mathrm{y}$-lactones by the reaction of manganic acetate with olefins. J. Am. Chem. Soc. 1968; 90(21):5905-6. (b) Bush JB Jr, Finkbeiner $\mathrm{H}$. Oxidation reactions of manganese(III) acetate. II. Formation of $\mathrm{Y}$-lactones from olefins and acetic acid. J. Am. Chem. Soc. 1968; 90(21):5903-5. (c) Heiba EI, Dessau RM. Oxidation by metal salts. XI. Formation of dihydrofurans. J. Org. Chem. 1974; 39:3456-7.

23. Williams GJ, Hunter NR. Situselective $a^{\prime}-$ acetoxylation of some $a, \beta$-enones by manganic acetate oxidation. Can. J. Chem. 1976; 54(24):3830-2.

24. Tanyeli C, Caliskan ZZ. A Facile Synthesis of Various Butenolides. Synth. Commun. 2000; 30(16):2855-62.

25. Demir AS, Caliskan Z, Aydın AE, Bicer I. A new and efficient chemoenzymatic route to both enantiomers of $a^{\prime}$-acetoxy and $a^{\prime}$-hydroxy-amethoxy cyclic enones. Tetrahedron: Asymmetry. 2006; 17:786-91.

26. Ashok K, Kartik D, Shamsher SK, Pankaj KA. Lipase catalysis in organic solvents: advantages and applications. Biol Proced Online. 2016; 18/2: 1-11.

27. [URL]

28. Shih-Hsiung Wu, Su-Yuan Lai, Shu-Ling Lin, Fei-Ya Chu, Kung-Tsung Wang. Enantiomeric separation of 2-(phenoxy)propionate derivatives by chiral high-performance liquid chromatography. Chirality. 1991; 3(6):476-9. 
